the art work and Maria Eugenia Goñi for her secretarial assistance.

R Martínez y Martínez, E Corona-Rivera, M JiMÉNEZ-MARTÍNEZ, R OCAMPO-CAMPOS, S García-Maravilla, and J M Cantú División de Genética, Subjefatura de Investigación Cientifica, Unidad de Investigación Biomédica y Hospital de Pediatría, Centro Médico de Occidente, Instituto Mexicano del Seguro Social, Apartado Postal 1-3838, Guadalajara, Jalisco, Mexico.

References

1 Tamari I, Goodman RM. Upper limb-cardiovascular syndromes. A description of two new disorders with a classification. Chest 1974;65:632-9.

2 Cantú JM, Hernández A, Ramírez J, et al. Lethal faciocardiomelic dysplasia. A new autosomal recessive disorder. Birth Defects 1975;XI(5):91-8.

3 McKusick VA, Engeland JA, Elridge R, Krusen DE. Dwarfism in the Amish. I. The Ellis-van Creveld syndrome. Bull Johns Hopkins Hosp 1964;115:306-36.

4 Kaufman RL, Hartman AF, McAlister WM. Family studies in congenital heart disease. II. A syndrome of hydrometrocolpos, postaxial polydactyly and congenital heart disease. Birth Defects 1972;VIII(5):85-7.

Requests for reprints to Dr R Martínez, y Martínez, División de Genética, Unidad de Investigación Biomédica, Apartado Postal 1-3838, Guadalajara, Jalisco, Mexico.

\section{Prenatal diagnosis for adenosine deaminase deficiency}

SUMMARY Amniocentesis was performed in two successive pregnancies of the mother of a child with adenosine deaminase (ADA) deficient severe combined immunodeficiency. Assay of ADA in amniotic fluid fibroblasts showed the pregnancies to be normal and homozygous deficient, respectively. These findings were confirmed by the demonstration of a normal level of erythrocyte ADA in the cord blood of the healthy male born of the first pregnancy and by the demonstration of undetectable ADA activity in cord erythrocytes, spleen, liver, and kidney of the abortus of the second pregnancy. Prenatal diagnosis of ADA deficiency appears to be a reliable procedure.

Deficiency of the purine catabolic pathway enzyme ADA represents the first inborn error of metabolism

Received for publication 4 June 1980

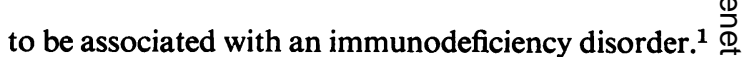
The clinical significance of this association has been exploited in a number of ways. Where a family has $\stackrel{f}{?}$ had a child with severe combined immunodeficiency, $\bar{C}$ the finding of ADA deficiency can be useful 을 for genetic counselling, since it indicates an auto- $\frac{\bar{\rho}}{\vec{D}}$ somal recessive mode of inheritance. Enzyme re- $\stackrel{\mathbb{Q}}{\Omega}$ placement appeared feasible since the enzyme is abundant in erythrocytes and successful correction $\vec{\theta}$ has been achieved, ${ }^{23}$ though such success is not invariable. ${ }^{4}$ Intrauterine diagnosis is possible since $\overrightarrow{\vec{\omega}}$ ADA is widespread in tissues. Hirschhorn et $a l^{6} \stackrel{\omega}{\omega}$ reported the diagnosis of this deficiency in a 28-week fetus. The pregnancy proceeded and the deficiency was confirmed at delivery. The purpose of this com- $\vec{\infty}$ munication is to report that prenatal diagnosis has ? been performed successfully in two pregnancies of a $\overrightarrow{\mathrm{N}}$ woman who had previously born an ADA deficient child.

\section{Case report}

The case history, clinical and laboratory findings, $\vec{\varnothing}$ and details of management of the proband have been reported elsewhere. ${ }^{5}$ Briefly, a first-born male was $\square$ referred at 14 weeks with failure to thrive, recurrent bacterial infection, thrush, diarrhoea, and cough with respiratory distress. Tonsillar and peripheral lymphoid tissue were deficient. $X$-rays showed absent $\stackrel{\circ}{\mathbb{D}}$ thymic shadow, interstitial pneumonitis, and skeletal findings suggestive of ADA deficiency. Immunological studies showed severe combined immunodeficiency, ADA deficiency was shown in red blood cells and leucocytes, and the parents were found to be heterozygous deficient. A family study has been reported elsewhere. ${ }^{7}$ Therapy included gammaglobulin replacement, erythrocyte and plasma 3 . infusions, and fetal liver transplants, but was unsuccessful and the patient died at age 17 months of a parainfluenza pneumonitis. The mother of this child has since had two pregnancies and prenatal diagnosis was offered for both (see below). The first of these proceeded to term and produced a healthy infant. The second was terminated at 22 weeks' gestation. $\widetilde{N}$

Methods

Amniotic fibroblast cultures were performed as de- $\stackrel{0}{2}$ scribed. ${ }^{8}$ Amniotic fluid was collected at 14 to 16 을 weeks' gestation and set up in $25 \mathrm{~cm}^{2}$ flasks (Falcon $\mathbb{D}$ Plastics) in Ham's F10 medium buffered with $25 \stackrel{-}{-}$ $\mathrm{mmol} / \mathrm{l}$ Hepes. For ADA assay, cells were lysed directly from the flask.

ADA assay on all tissues examined was determined $\stackrel{\mathbb{\Omega}}{\stackrel{\Omega}{\circ}}$ by an isotopic method previously described in detail. ${ }^{9} \stackrel{\mathbb{2}}{\varrho}$ Tissue homogenate or cell suspensions in $10 \mathrm{mmol} / 1$ 㝏 
tris $(\mathrm{pH} \mathrm{7.4)}$ were rapidly frozen and thawed, and centrifuged at $10000 \mathrm{~g}$ for 20 minutes. The supernatants were dialysed against $100 \mathrm{vol} 10 \mathrm{mmol} / \mathrm{l}$ tris $\left(\mathrm{pH} \mathrm{7.4)}\right.$ at $4^{\circ} \mathrm{C}$ for 24 hours. A $50 \mu l$ quantity of cell extract in $100 \mu \mathrm{l}$ of $50 \mathrm{mmol} / \mathrm{l}$ tris $(\mathrm{pH} 7 \cdot 0)$ with 0.4 $\mathrm{mmol} / 1{ }^{14} \mathrm{C}$-adenosine $(2 \mathrm{mCi} / \mathrm{mmol})$ was incubated at $37^{\circ} \mathrm{C}$, and reactions terminated by addition of $50 \mu l$ absolute alcohol. This was then incubated at $95^{\circ} \mathrm{C}$ for 2 minutes and clarified by centrifugation at $2000 \mathrm{~g}$ for 5 minutes. Conversion to ${ }^{14} \mathrm{C}$-inosine was determined by chromatography on Whatman CM-82 paper.

\section{Results}

The adenosine deaminase activities in amniotic fluid fibroblasts obtained from 30 pregnancies for indications other than potential immune deficiencies are shown in the figure. The specific activity of ADA showed a non-bimodal distribution with an arith-

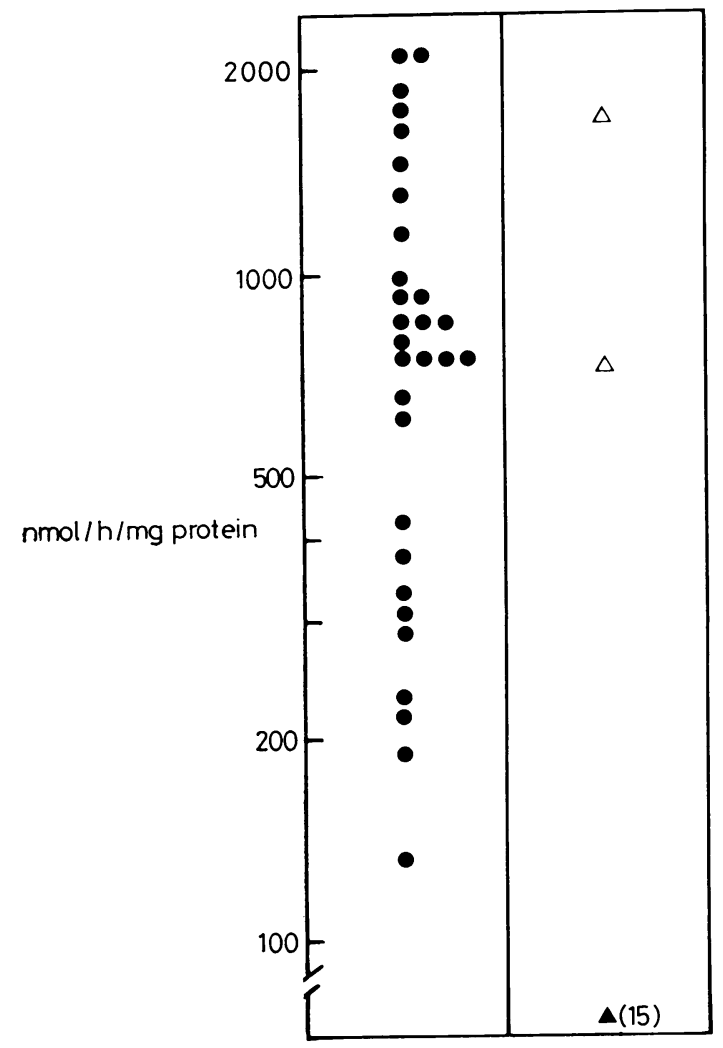

FIGURE Adenosine deaminase activity in amniotic fibroblasts of control pregnancies $(\bullet)$ and two consecutive pregnancies $(\Delta, \Delta)$ of a mother with a previous $A D A$ deficient child. metic mean of $803 \mathrm{nmol} / \mathrm{h} / \mathrm{mg}$ protein and a range of 130 to $2250 \mathrm{nmol} / \mathrm{h} / \mathrm{mg}$ protein, values corresponding favourably with those reported by others. ${ }^{6} 10$ Results of ADA determinations on fibroblasts taken from the two pregnancies under study are also shown. Two separate fibroblast cultures were maintained after amniocentesis at 14 weeks in the first of these pregnancies and ADA assay gave results of 738 and $1740 \mathrm{nmol} / \mathrm{h} / \mathrm{mg}$ protein, values compatible with normal ADA status. The pregnancy proceeded and a healthy male child was born at term. ADA level on cord erythrocytes was $115 \mathrm{nmol} / \mathrm{h} / \mathrm{mg}$ protein (normal range 53 to 120). This infant, when reviewed at age 22 months, was growing and developing normally with no history of infections of note.

With the next pregnancy, cells obtained at 15 weeks' gestation grew poorly and were inadequate for enzymatic assay. A second amniocentesis was performed at 18 weeks. Again these cells grew poorly and exhibited an ADA activity of $15 \mathrm{nmol} / \mathrm{h} / \mathrm{mg}$ protein. The pregnancy was terminated at 22 weeks and ADA activity was undetectable in cord erythrocytes, kidney, liver, and splenic extracts of the abortus.

\section{Discussion}

These experiences appear to validate the role of prenatal diagnosis in families with ADA deficiency. One cautionary note is the wide range of ADA activity in ADA positive amniotic fluid fibroblasts, a phenomenon noted by others ${ }^{6} 10$ and suggested to be related to cell cycle. ${ }^{11}$ For clinical purposes we suggest that ADA deficiency should be considered if the measured activity approximates $10 \%$ that of the lower normal range. Our difficulty in growth of sufficient numbers of ADA negative amniotic fluid fibroblasts may have been purely coincidental. However, although ADA negative human lymphoblasts proliferate without difficulty in vitro, ${ }^{12}$ the metabolic consequences of this deficiency may have different implications for human amniotic fluid fibroblasts, and difficulty in growth in the absence of obvious causes may be another indicator of ADA deficiency.

\section{John B Ziegler, Martin B Van Der Weyden,} Choon H Lee, AND ARt Daniel Prince of Wales Children's Hospital, Randwick, NSW; Alfred Hospital, Prahran, Victoria; and Prince Henry Hospital, Little Bay, NSW, Australia

\section{References}

1 Giblett ER, Anderson JE, Cohen F, Pollara B, Meuwissen $\mathrm{HJ}$. Adenosine deaminase deficiency in two patients with severely impaired cellular immunity. Lancet 1972 ;ii:1067-9. 
2 Polmar SH, Stern RC, Schwartz AL, Wetzler GM, Chase PA, Hirshhorn R. Enzyme replacement therapy for adenosine deaminase deficiency and severe combined immunodeficiency. $N$ Engl J Med 1976;295:1337-43.

3 Uberti J, Lightbody JJ, Wolf JW, Anderson JA, Reid RH, Johnson RM. The effect of adenosine on mitogenesis of ADA-deficient lymphocytes. Clin Immunol Immunopathol 1978;10:446-58.

4 Schmalstieg FC, Mills GC, Nelson JA, May LT, Goldman AS, Goldblum RM. Limited effect of erythrocyte and plasma infusions in adenosine deaminase deficiency. $J$ Pediatr 1978;93:597-603.

5 Ziegler JB, Lee CH, Van der Weyden MB, Bagnara AS, Beveridge J. Severe combined immunodeficiency and adenosine deaminase deficiency: failure of enzyme replacement therapy. Arch Dis Child 1980;55:452-7.

- Hirshhorn R, Beratis N, Rosen FS, Parkman R, Stern R, Polmar S. Adenosine deaminase deficiency in a child diagnosed prenatally. Lancet 1975 ;i:73-9.

7 Lee CH, Rozenberg MC, Ziegler JB. Family study on the kindred of an adenosine deaminase deficient child with severe combined immunodeficiency. Aust NZ J Med $1979 ; 9: 530-3$.

8 Daniel A, Lam-Po-Tang PRLC. Prenatal diagnosis in New South Wales: comparative view of the first 1000 cases of chromosome, sex-linked, and metabolic referrals. Med J Aust 1978;ii:352-7.

9 Van der Weyden MB, Bailey L. A micro-method for determining adenosine deaminase and purine nucleotide phosphorylase activity in cells from human peripheral blood. Clin Chim Acta 1978;82:179-84.

10 Chen SH, Scott RR, Swedberg KR. Heterogeneity for adenosine deaminase deficiency: expression of the enzyme in cultured skin fibroblasts and amniotic fluid cells. $\mathrm{Am}$ J Hum Genet 1975;27:46-52.

11 Uitendaal MP, de Bruyn CHMM, Oei TL, Geerts SJ, Hösli P. Fluctuating adenosine deaminase activities in cultured fibroblasts. Biochem Med 1978;20:54-62.

12 Van der Weyden MB, Jack I, Lee CH, Ziegler JB. The establishment of an adenosine deficient lymphoblastoid cell line. Proc Aust Soc Med Res 1977;10:960.

Requests for reprints to Dr J B Ziegler, Prince of Wales Children's Hospital, Randwick, NSW 2031, Australia.

\section{Propionyl coenzyme A carboxylase deficiency presenting as non-ketotic hyperglycinaemia}

SUMMARY A 4-month-old girl presented with myoclonic seizures and an electroencephalogram showing hypsarrhythmia. Hyperglycinuria and a cerebrospinal fluid to plasma glycine ratio of 0.2 suggested the diagnosis of non-ketotic hyperglycinaemia. Propionic acid and methyl citric acid were present in the urine, and propionyl coenzyme A carboxylase was deficient in leucocytes and fibroblasts. The ketotic and non-ketotic hyperglycinaemias cannot be differentiated by CSF: plasma glycine ratios.

Received for publication 9 May 1980
Hyperglycinaemic syndromes in children may assume $\stackrel{\vec{Q}}{?}$ either ketotic or non-ketotic forms. Children with $\Rightarrow$ non-ketotic hyperglycinaemia frequently exhibit $\stackrel{\oplus}{\stackrel{\oplus}{+}}$ myoclonic seizures and an absence of voluntary을 muscle movement. Although few survive the recurrent acute crises in infancy, those who do $\frac{\bar{\rho}}{\vec{D}}$ usually become spastic and profoundly delayed $\stackrel{\Phi}{\mathscr{Q}}$ developmentally. On the other hand, ketotic hyperglycinaemia is clinically characterised by intermittent $\vec{A}$ attacks of ketoacidosis and hyperammonaemia, which may cause vomiting, hypotonia, and lethargy, $\vec{\omega}$ progressing to coma or ultimately death in the o neonatal period. ${ }^{1}$ The glycine cleavage system, $\bar{\Xi}$ which converts glycine to serine, is deficient in the cerebral tissue of children with non-ketotic hyper- $\infty$ glycinaemia. Raised brain glycine content and a cerebrospinal fluid glycine to plasma glycine ratio $\vec{G}$ exceeding 0.03 , in conjunction with clinical differ- 0 ences, was proposed as a discriminator of non- ketotic from ketotic hyperglycinaemia. ${ }^{2-4}$ Ketotic $\vec{D}$ hyperglycinaemia is the consequence of deficient propionyl coenzyme A carboxylase, methylmalonyl coenzyme A mutase, $\beta$-ketothiolase, or isovaleryl $\varnothing$ coenzyme A dehydrogenase activity, ${ }^{5}$ none of which $\cdot$ appears to affect CSF glycine concentration.

\section{Case report}

A 4-month-old girl was referred to us with the $\frac{\circ}{\otimes}$ classical features of non-ketotic hyperglycinaemia, $\stackrel{2}{\rightrightarrows}$ including excessive glycinuria, myoclonic seizures with a typical hypsarrhythmic electroencephalographic pattern, and a CSF-to-plasma glycine concentration of $0 \cdot 2$. However, despite the absence of ketoacidosis and hyperammonaemia, she was found to have propionic acidaemia and deficient propionyl coenzyme A carboxylase activity. Seizure 3 activity stopped one week after the introduction of ACTH gel therapy and her electroencephalogram reverted to a normal pattern. During the severe 0 illness, plasma glycine was $1154 \mu \mathrm{mol} / \mathrm{l}$ (normal 175 to 296 ), propionate, $153 \mu \mathrm{mol} / 1$ (normal $<3$ ), $\frac{D}{0}$ and caprylate, $100 \mu \mathrm{mol} / 1$ (normal $<3$ ). The cerebrospinal fluid glycine was $213 \mu \mathrm{mol} / 1$ (normal 3- N 10). On gas chromatography/mass spectroscopy $N$ raised concentrations of 3-hydroxypropionate, fuma- N rate, $p$-hydroxyphenylacetate, and methyl citrate $\omega_{0}$ were evident in the urine. Propionyl coenzyme $A$ \% carboxylase activity was deficient in leucocytes and $\stackrel{O}{=}$

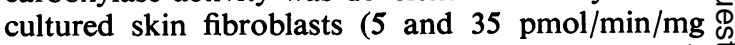
protein, respectively, compared with the correspond- ing normal activities of $349 \pm 51$ and $863 \pm 102$ $\mathrm{pmol} / \mathrm{min} / \mathrm{mg}$ protein). The fibroblast cell line was $\underset{\mathbb{D}}{\stackrel{\mathrm{D}}{\mathrm{N}}}$ assigned to the $p c c B C$ complementation group ${ }^{6}$ and $\stackrel{\stackrel{\rho}{\mathbb{D}}}{\sigma}$ was shown to be unresponsive to biotin. The patient's $\cong$ disorder was managed by dietary protein restriction 